\title{
PRIMARY MORTGAGE INSTITUTIONS CHALLENGES FOR FINANCING HOUSING DEVELOPMENT IN NIGERIA
}

\author{
Zubairu Abubakar Ghani ${ }^{*}{ }^{\circledR}$ \\ *1 Department of Urban and Regional Planning, Faculty of Environmental Technology, \\ Abubakar Tafawa Balewa University, P.M.B. 0248, Bauchi, 740272 Nigeria
}

DOI: https://doi.org/10.29121/granthaalayah.v9.i2.2021.3099

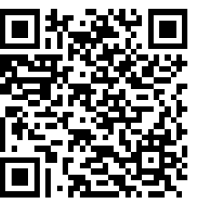

Article Type: Research Article

Article Citation: Zubairu Abubakar Ghani. (2021). PRIMARY

MORTGAGE INSTITUTIONS

CHALLENGES FOR FINANCING

HOUSING DEVELOPMENT IN

NIGERIA. International Journal of

Research -GRANTHAALAYAH, 9(2), 127-137.

https://doi.org/10.29121/granthaa

layah.v9.i2.2021.3099

Received Date: 13 January 2021

Accepted Date: 26 February 2021

Keywords:

Primary Mortgage Institutions

Housing Fund

Housing Finance

Low and Medium Income Groups

Conditions Attached

Accessibility

\begin{abstract}
Housing provision, is a capital intensive, which requires huge financial obligations, the requirement that is tough to meet by many households, thereby leading to ever-increasing housing stock deficit in Nigeria. Over the years, government made some efforts trying to meet up with housing finance demands of the citizens through the creation of mortgage institutions to mobilise and facilitate housing finance, delivery and ownership, especially among the low and medium income groups. Despite all efforts, conditions attached to housing finance, accessibility remained a clog in the wheel of housing provision and ownership to especially low and medium income groups. The purpose of this research is to investigate accessibility of Primary Mortgage Institutions housing finance by potential consumers. The paper explored qualitative research methodology in data collection and analysis using Nvivo tool. It was found, conditions attached to housing finance accessibility remained the primary factor that deprived most of the prospective borrowers. Therefore, accessing housing finance from the Primary Mortgage Institutions remain a key challenge to most low and medium income groups which also hampered housing provision and ownership.
\end{abstract}

\section{INTRODUCTION}

Housing can be regarded as one of the basic needs, in life to man after food and clothing. Many studies concurred housing is a first and foremost basic human need. Psychologically, housing is one of the most important, necessities of life; it is a priority for the attainment of living standard and is the core of the man-environmental interaction. Housing is a long-term asset and house ownership helps to create stakes in the peace, stability and prosperity of households and housing development programmes can be used to stimulate economic activities (Ademiluyi \& Raji, 2008 and Cagamas Holdings, 2013). Housing makes people feel comfortable, safe and has a high sense of pride, hence living in high-end houses, conveys privilege, economic well-being and high social status of people and on the contrary, living in low-end houses, makes people feel bored, dejected and delinquent. Everyone should, therefore, expect to have access to a good-quality house and a pleasant environment that makes the occupants happy and contented. Owning a house is a major goal for every household in any society and the efficiency and effectiveness, of the housing delivery system, will be a major social and economic objective of households. However, adequate and

(C) 2021 The Author(s). This is an open access article distributed under the terms of the Creative Commons Attribution License, which permits unrestricted use, distribution, and reproduction in any medium, provided the original author and source are credited. 
decent, housing ownership over the years remained just a wish to many Nigerians especially the low-income earners who cannot marshals resources and labour to construct their houses.

Nigeria has been regarded as the most populous country in Africa with an estimated population of 201 million (Population Reference Bureau [PRB], 2019) and with a housing deficit of over 17 million housing units (Ayedun and Oluwatobi, 2011). In spite of government efforts over the years, in trying to meet up with housing demand, always the supply, remained far short of the demand and housing stock remains inadequate. In housing provision, there are many factors influencing delivery and ownership, such as land acquisition, housing finance, cost of building materials, cost of construction and construction technology which hamper housing provision and ownership among households at varying degrees.

Housing provision, through the creation of mortgages, is taken for granted, in Nigeria however, it remains a major challenge in housing delivery system and ownership especially among the middle and low-income groups. Despite years efforts of previous governments to develop mortgage institutions for housing financing, yet to have vibrant mortgage institutions and market for effective and efficient housing delivery performance in Nigeria (Akeju, 2007). This may not be unconnected to the lending policies and capital base of the mortgage institutions and on the other hand, affordability status of the potential clients (borrowers). In line with this, Ayedun and Oluwatobi (2011) reported, the majority of the primary mortgage institutions operating in Nigeria are not much different from conventional commercial banks, moreover, their capital base is to some extent, weak to support the requirements of prospective borrowers for housing construction. Inevitably, lack of sufficient and reasonable financial instruments to provide loans to the middle and lower income groups, being the majority of the income landscape of Nigeria, makes it difficult for many households to afford their own houses. However, easy accessibility to housing funds (mortgage loan) for constructing or buying a house can drive up many low and middle income households toward house ownership (Lee, Ho \& Chiu, 2016). Therefore, housing finance, is of a critical issue in housing provision hence all other factors, directly or indirectly, has financial implications attached to them. Although, there are many challenges to housing provision in Nigeria, where housing finance, is a key challenging issue which mortgage institutions (housing finance) are expected to address but the situation seems to be no improving significantly which this paper seeks to discuss.

\section{BACKGROUND OF THE STUDY}

History of house ownership is inseparable from the context of the social, economic and political development of human beings. Socially and economically, house ownership, is loaded with a symbolic value of economic status and an expression of style and manner in which society inspire their environment to be. In other words, housing, in general, is a symbol reflecting social status and economic values of individual and or society (Ghani, 1992 \& Alaka et al., 2012), fundamental element that physically expressed socio-cultural values of any given society and expression of societal identity or economic status. In line with this, Aluko (2011) sees housing as a reflection of the cultural, social and economic values of a society as it is the best physical and historical evidence of civilization in a country. It also has value for its location (Ghani, 1992), for the access it provides to neighbourhood facilities and for the opportunity to live in a neighbourhood of one's choice. Similarly, Schwartz (2006) opined, housing is a major, asset for homeowners and the most widespread form of personal wealth in a society. According to Cagamas Holdings (2013), 'housing ownership has vast economic, social and political spinoffs. Houses are investment assets that grow in value over time and are, therefore, means of saving and wealth accumulation'. Therefore, viewing house ownership in socioeconomic values, Jiboye (2010) simply, sum up and concluded, the economic values of a house, should not be over emphasis hence "housing is a major economic asset in every nation".

Housing provision in many countries takes simply two forms of provisions either conventional or nonconventional. Conventional housing provision, simply, means a form, of housing provision, where government or corporate organizations, dominate the process, while, the non-conventional, is dominated by informal procedures. In Nigeria, housing provision is largely, dominated by the non-conventional as Keivani \& Werna (2001) referred it to 'non-public sector' through which the majority of the houses, for the middle and low-income groups, are provided. In this system, the majority of the middle and low-income housing provisions are attained, through various modes of housing provisions like private households, community, cooperatives and other informal private sectors, are already involved at different degrees, as agents of low-income housing provision. 
Indeed housing provision is perceived as a long-term investment that involves huge financial commitment, the requirement that is hard to meet by many families, thereby leading to the ever-increasing deficit of housing stock in many countries especially the developing countries which Nigeria is not exceptional. The fact that housing provision is capital intensive and world economic crisis aggravated the housing problems across the world as reported by the United Nations that there were more than 233 million housing units deficit estimated in developing countries out of 323 million housing unit deficits for the whole world. Similarly, according to Ayedun and Oluwatobi (2011) and Abeku, Salihu, \& Kure (2016), in Nigeria, housing deficit is reported to have shown continuously increasing with almost 8 million housing units in 1991, between 12 to14 million housing units in 2007 and between 16 to 17 million housing units deficit in 2015. With such a startle figure of housing shortfalls, Nigeria needs sound and effective housing delivery system and a huge amount of funds to close up the wide gap between the needs and supply.

Despite numerous housing delivery policies and programmes embarked in Nigeria, like mass housing provision of 1981 which targeted 202,000 housing units and yet the housing provision is lagging far behind the needs of the citizenry. This includes, also the establishment of the apex and primary mortgage institutions purposely for mobilizing financial resources for housing provision as well as to encourage house ownership. Many works of literature have reported, failure of Nigeria housing policies and programmes, such studies include Ayedun and Oluwatobi (2011), Abeku et al., (2016), Akeju (2007), Folorunso, Khan, \& Olowoyo (2012), Ademiluyi \& Raji (2008), Ahmed (2014) and Keivani \& Werna (2001). They reported that for many years, Nigeria has been pursuing welldesigned housing policies and programmes, unfortunately, were not successfully materialized, despite engulfing large sum of money. Pathetic situation of the Nigerian housing programmes is that entangled by low political willpower and corruption which led to miserable failures of the programmes (Keivani \& Werna, 2001) and the housing programmes were ended up just in squandering the resources allocated to the projects.

Indeed, problems of housing provision in Nigeria are many and complex while effective solutions to them are yet to be found. Along the line, many studies posit that housing finance; the cost of land and building materials are the key factors of housing provision problems (Keivani \& Werna, 2001; Sivam, 2003; Akeju, 2007; Ayedun \& Oluwatobi, 2011 \& Folorunso et al., 2012). Similarly, it was opined finance is the most important, singular element needed, to mobilize materials and labour resources required to actualize various goals of the housing policies and schemes (Folorunso et al., 2012). However, finance inadequacy is the major, deterrent to effective provision and acquisition of affordable housing especially among the low and medium income earners in Nigeria.

In trying to get the solutions of housing finance problems in the country, Nigerian Building Society (NBS), was established as far back in 1956, then in 1977, Decree No. 7 was promulgated for the establishment of Federal Mortgage Bank of Nigeria (FMBN) to replace the NBS as housing finance agency and the bank commenced operations on July 1st, 1977. The FMBN remained largely, the major provider, of long-term funds in the housing finance sector for all potential borrowers up to 1989 when the mortgage institutions ACT No. 53, was promulgated for the establishment of Primary Mortgage Institutions (PMIs) to support the activities of the FMBN (http://www.fmbn.gov.ng/doc/CorporateHistory \& Folorunso et al., 2012). The Act, transformed the FMBN, as an Apex mortgage institution responsible for providing long-term loan facilities to primary mortgage institutions; regulating and supervision of the primary mortgage institutions (PMIs), also provision of long-term loan to individual and corporate property developers for housing provision and to carry out research on mortgage finances (Akeju, 2007; Ojo \& Song 2009; Ayedun \& Oluwatobi, 2011; Folorunso et al., 2012 \& FMBN, 2016). Following slow pace of PMIs performance, Nigerian government established yet another housing finance institution called National Housing Fund (NHF) by the enactment of Act No. 3 of 1992 to serve as a central pool for facilitating and mobilization of funds from workers obligatory monthly contributions for the provision of long-term housing loan (Folorunso et al., 2012; FGN 1992 \& FMBN, 2016). According to Chen \& Deng (2014), the obligatory monthly contributions, ensures steady, low-cost and long-term funding to proffer subsidised mortgage loans for the contributors. Furthermore, government mandated insurance companies to invest their $20 \%$ non-life and $40 \%$ life funds into the housing while commercial and merchant banks to invest $20 \%$ of their loans and advances to housing sector purposely to ease housing finance problems and to facilitate housing delivery and ownership among Nigerians.

All these efforts are tailored, towards solving problems of housing finance and to encourage house ownership at an affordable price to reduce the housing deficit to the barest minimum in the country. Although, housing finance through formal mortgage institutions is thought to be the solution to housing problems, but according to Quansah \& Debrah (2015), in many developing countries, formal mortgage institutions are not successful. This is confirmed by Nubi (2000) who reported, in Nigeria about 245 PMIs were established between 1991 and 1996 but, only 22\% were found to be operating in the year 2000. However, on other side of the coin, enforcement of affordability programme 
of housing finance was weak (MacDonald, 2012) which added to the persistent problem. This is attributed, to many factors ranging from a low capital base, low purchasing power of the potential borrowers, cost of building materials and land issues among others. In similar way Folorunso et al., (2012) believed, the high cost of building materials, inflation, low purchasing power and lack of public and corporate finance in the sector, can be considered as the most significant reasons for inadequate housing provision. Also Quansah \& Debrah (2015) attributed the problems to the persisting rapid inflation and slow economic growth among other negative economic indicators in developing countries.

On the other hand, many studies re-iterated mortgage lending policies are burdensome which also play significant roles in hindering many middle and low-income households access to housing finance to own their dream houses. According to Ayedun \& Oluwatobi (2011) the "mortgage instruments in operation" are cumbersome and stringent conditions attached to the accessibility of the fund thereby making access to the mortgage funds by interested borrowers, especially the middle and low-income households, almost impossible and unattainable. Under normal circumstances, mortgage loans, are constantly surrounded by prescriptive and inhibitive conditions, that are stringent and punitive which inadvertently, bogged down the low and medium income groups to access the loan, in turn, cause bottleneck in housing provision and home-ownership. Sierminska \& Takhtamanova (2012) observed, mortgage thorny loan terms, can limit access to the loan and reduce home ownership. Chen \& Deng (2014) hypotheses, housing loans from mortgage institutions have much strict underwriting criteria, the amount of loan is capped and the loan interest rate doesn't have much advantage compared to that of commercial banks. Accordingly, Folorunso et al., (2012), attributed the problems of accessibility to mortgage loan facilities, to high-interest rate on loans that have impeded and scared prospective borrowers from achieving their dream of ever owning a personal house. Interest rate and administrative bureaucracy involved in mortgage loans present limitation to low income groups and a challenge to housing delivery in Nigeria (Chidi-Okeke \& Nwanna, 2020). Considering the stringent conditions attached to the formal mortgages, Sivam (2003) concluded, low and middle-income households, do not have significant access to the formal system of housing finance and considered, these people, are deprived of institutional loan facilities for housing, hence, they do not have security and thus cannot fulfil the conditions. Consequently, households, are critically challenged by their ability to raise housing funds through individual families saving which remain the prime sources, of financing housing development in many developing economies like Nigeria. Lee, Ho \& Chiu (2016) hypothesised that, private savings and loans from relatives are also among the available fund sources for housing and played significant roles in constructing or buying house for low and middle income groups. Therefore, majority of houses for the middle and low-income groups, are provided, through the informal sector (self-help) hence, their accessibility to mortgage loan facilities, remain almost impossible (Keivani \& Werna, 2001) and the housing provision problems persist. This prompted Chen \& Deng (2014) to observed, these loan lending conditions, led to inequality in policy, raised potential borrowers to dissatisfaction and distance them to access the loan.

\section{METHODOLOGY}

This paper employed qualitative method of data collection and analysis, an expert interview was used as the instrument for the research data collection. A semi-structured questionnaire was adopted and one-to-one interview method was employed, for detailed investigation of the research phenomena from people's personal opinions and experiences for in-depth subject coverage and understanding of the research contextual issues (Berg, 2001, Creswell, 2014, Gibson and Brown, 2009, Naoum, 2007 \& Ritchie, 2013).

In drawing the research samples, convenient sampling technique was used where the participants were selected because they are easily accessible and willing to participate in the research as recommended by Creswell (2014) and Ritchie et al., (2003) which will enable detailed exploration and understanding of the central themes. Seven participants were selected, as a sample for the research data sources, personal interviews were conducted, in December 2019 through March 2020 and English language was used as the communication medium. The interview transcripts, were carefully examined and the textual themes were identified for coding the data and content analysis as suggested by Creswell (2014) and Ritchie (2013) whereas, NVivo version 10, was the data analysis tool employed. Table 1 summarised the research sample attributes from which the data were sourced.

Table 1: Research participants attribute

\begin{tabular}{|l|l|l|l|l|l|l|}
\hline Participants & Gender & Age & Education Level & Occupation & GL & House tenure \\
\hline
\end{tabular}


Zubairu Abubakar Ghani

\begin{tabular}{|c|c|c|c|c|c|c|}
\hline Participant 1 & M & 34 & HND & Civil Servant & 9 & Renting \\
\hline Participant 2 & M & 33 & ND & Civil Servant & 6 & Owned \\
\hline Participant 3 & M & 48 & Certificate & Civil Servant & 4 & Renting \\
\hline Participant 4 & M & 45 & Certificate & Civil Servant & 3 & Renting \\
\hline Participant 5 & M & 40 & Degree & Civil Servant & 12 & Owned \\
\hline Participant 6 & F & 38 & Degree & Civil Servant & 9 & Husband's \\
\hline Participant 7 & M & 37 & Certificate & Business & N/A & Owned \\
\hline
\end{tabular}

\section{RESULTS AND DISCUSSION}

\subsection{PRIMARY MORTGAGE INSTITUTIONS}

Transformation of the Nigeria Building Society (NBS) to Federal Mortgage Bank of Nigeria (FMBN) in 1977 and promulgated ACT No. 53, gave birth to Primary Mortgage Institutions (PMIs), as Nigeria's housing finance institutions, aimed at providing a long-term loan to individuals for housing development and encourage home ownership. After the establishment of PMIs, the FMBN was accorded the status of Apex Mortgage Bank and assigned the responsibilities of providing long-term loan and regulating (supervisory) functions to the PMIs, as well as providing a long-term loan, to individuals and residential estate developers. Moreover, in 1992, ACT No. 3, was promulgated that established National Housing Fund (NHF) which is another scheme, aimed, to facilitate continuous mobilization and flow of housing funds for long-term from a compulsory monthly deductions as contribution from both public and private workers' salary/income for long-term housing investment. Functions of FMBN expanded as it was assigned to manage the NHF funds. The scheme mandated all Nigerian age 21 years old and above in paid employment with monthly salary income of $\$ 3,000.00$ and above to contribute $2.5 \%$ of their monthly salary to the fund through FMBN for the purpose of building, purchasing or renovating residential houses at a relatively low interest rate of $6 \%$. Furthermore, under the reform of housing sector of National Housing and Urban Development Policy of 2002, the FMBN was restructured into a Federal Government Sponsored Enterprise (FGSE) with more focus on secondary (Apex) mortgage and capital market functions. Indeed, housing funds policies, sound like an effective vehicle for mobilization, encouragement and increasing long-term housing loan services that tailored to solve the problems of housing delivery and encourage house-ownership but other problems attached (stringent conditions) to the mortgage lending, make it difficult for the prospective borrowers to access.

Although it has been a practice of financial institutions to place some security conditions for their financial deals to ensure recovery and defies fraudulent acts, nevertheless, they become barriers for many prospective customers to satisfy and access the facilities. Therefore, accessing the mortgage loans by the low and medium income groups is a major constraint towards home ownership. The PMIs' conditions for accessing housing loan include:

- collaterals (security): landed (mortgage) property for which the loan is sought shall serve as security for the loan, with sufficient value, to recover the loan;

- the property must have valid documents (certificate of occupancy [C of O]; right of occupancy [R of O], Deed of Sublease, Deed of Assignment or Letter of Allocation);

- the property shall conform to the existing planning laws \& regulations and building plans approved by the appropriate authorities;

- the mortgaged property must be insured against hazards; \&

- applicants must accept to take up both "Fire Insurance Policy" \& "Mortgage Protection Policy”.

Anyone of the requirements may serve to some extent, as stringent to most of the borrowers more especially the low and middle-income groups. On the issue of mortgage property, valid documents, like C of O; Deed of Sublease, Deed of Assignment or Letter of Allocation and Consent to Mortgage, for which the loan is applied are intractable issues hindering many potential borrowers to access PMIs housing loan hence majority do not have the mortgage property less valid documents. This supported Chen \& Deng (2014) observation, loan lending conditions led potential borrowers to dissatisfaction and distance them to access the loan. Similarly, Sierminska \& Takhtamanova (2012) opined, high degree of mortgage regulations or difficult loan terms, usually work in the opposite direction which ultimately, can limit credit availability or access to the loan and then, reduce home ownership. This admitted, any society with stringent mortgage terms and or least developed mortgage market, will eventually limit access to 
housing loan for many potential borrowers and consequently, will have low homeownership rate. Although, these attached conditions were generally formulated out of necessity to ensure the loan repayment and defy fraudulent acts. Therefore, compliances of these conditions and administrative requirements, instead of facilitating access to the mortgage loan, may ostensibly translate into the bureaucratic delay and increase the cost of housing development, the issues that plagued most of the prospective borrowers. Thus, some research participants confirmed they do not have landed property for mortgaging to access the mortgage loan:

“I don't have land or house as collateral, so I cannot go for the mortgage loan because, I cannot fulfil their conditions" (participant4).

"I wanted to acquire a house or land and I have been trying for long, but could not, because, the cost is very high. I cannot buy any because saving for that is not easy and I cannot apply for a mortgage loan" (Participant3).

"I don't have land or house and you know, they asked for certificate before giving you a loan" (participant6).

However, among the participants, few of them have landed property, but find it difficult to undergo the process of obtaining the aforesaid valid documents because of the bureaucratic protocols involved such as cost implications, time taking (delay) and other requirements. Equally, it is tremendously stiff, to satisfy these conditions because most of the prospective applicants do not have the mortgage property and valid documents, the issue that hounded many households as some research participants elucidated. This affirmed Sierminska \& Takhtamanova (2012) and Chen \& Deng (2014) propositions, mortgage institutions have strict underwriting which distanced many households to access the loan. In addition, Ayedun and Oluwatobi (2011) postulated, the terms and conditions contained in most of the mortgage instruments are rather cumbersome and almost unattainable.

"Well, this is the biggest problem I have, though, I bought a piece of land last three years from land vendors. You know, they only give purchasing agreement and getting certificate is very difficult. So, I didn't go for it and is very difficult for me to apply for the loan" (Participant1).

"I bought land, from land speculators with no certificate and I did not apply for certificate or bank loan either because I am not interested" (Participant7).

"I inherited my house but the house, does not have a certificate and I find it difficult to apply for the certificate because they charge big money and take a long time (may be 2-3years) for the certificate to be prepared" (Participant2).

Whenever these conditions were not fulfilled, the PMIs, will not take risk of lending the loan and the housing loan cannot be accessed, therefore, posed problems to housing delivery and ownership. Critical challenge lay on households capability to generate finance for housing development, which compelled most of the low and medium income households, to continue with the traditional informal methods of financing and developing houses for themselves in tortoise pace, thereby making housing deficit ever increasing in Nigeria as the population continue to increase. This sustained difficult loan terms will eventually limit access to housing loan for many households and consequently, lower homeownership rate (Sierminska \& Takhtamanova, 2012). This confirmed Lee, Ho \& Chiu (2016) \& Keivani \& Werna (2001) proposition, substantial majority of houses for the low and middle income groups are provided through the traditional self-help and or soft loans from relatives (informal sector). Hence, access to conventional mortgage fund, is a major obstruction to effective building or acquisition of affordable housing especially among the low and medium income earners in Nigeria

"I built the house gradually, with my money, I think it took me almost four years to finish. No, bank loan but money from my business" (Participant7).

"I used my personal saving sometimes through thrift saving with my fellow colleagues, friends, and relatives to build the part of my house. It took me, I think five years, to have these three rooms." (Participant5).

"I started building my land, I already finished the foundation and any time I get chance (money), I will continue. You know as I told you, getting the certificate is very difficult, so, I did not apply for housing loan. I am using my saving from salary and other sources when an opportunity exists. You know, the saving is not regular, sometimes the saving collapse, when you have problems, you just withdraw from it and that is it." (Participant1).

NHF was introduced, with the sole aim of encouraging housing financing among Nigerians to enhance house ownership among low and medium income earners. The programme initially was targeted to serve employees on a 
salary basis by mandatory deduction of $2.5 \%$ of their monthly salary, but later included all Nigerians with regular income that will guarantee contribution to the fund like self-employed (non-salary) people. Primarily, the goal of the programme is to encourage housing finance and ensure all Nigerians own or have access to decent housing accommodation at affordable cost with secured tenure through the initiative of mortgage financing. FMBN is assigned, the responsibility of managing the NHF fund and the loan can be obtained through PMIs duly accredited and licensed by FMBN (Mortgage Loan Originator [MLO]).

However, eligibility for obtaining the NHF loan, the applicant must have satisfactory evidence of the regular flow of income to guaranteed loan repayment and must be a contributor to the fund for a minimum period of six months. The maximum amount of loan, obtainable under the NHF initially used to be $\$ 5$ million but has since been increased to $\$ 15$ million. This due to the high inflationary trend of building materials and cost of construction where an average cost of simple 2 bedrooms house range from 2.5-5 million Naira, though, depending on location. To become eligible for the loan, the prospective borrowers have to contribute $10-30 \%$ to the scheme of the total amount of the intended loan. Furthermore, potential borrowers, are entitled to a maximum of $\$ 15$ million but the condition pegged, no one shall be granted more than $90 \%$ of the total cost or value of the property to be mortgage and the loan is repayable over a maximum period of 30 years at a low interest rate of $6 \%$ per annum (FMBN, 2016). High degree of mortgage protocols, typically work in the inverse way which limit access to the loan (Sierminska \& Takhtamanova, 2012).

Indeed wages and income distribution structure in Nigeria is considered to be low which makes it difficult for prospective employees (borrowers) to contribute the said $10 \%$ of the intended minimum loan of 2 million. Presently minimum wage of employees in Nigeria has just been upgraded from $\$ 18,000.00$ to $\$ 30,000.00$ and if low-income group at $\$ 30,000.00$ minimum wage planned to borrow $\$ 2,000,000.00$, must contribute $10 \%$ of the amount ( $\mathrm{N} 200,000.00$ ) and the compulsory deduction of $2.5 \%$ of monthly salary ( $\$ 750.00$ ) is $\$ 9,000$ per annum and will take not less than 22 years to contribute the said $10 \%$ premium of the 2 million Naira loan $(\$ 200,000.00)$. On the account of $2.5 \%$ compulsory deduction, some research participants, shared their views, that it will yield nothing towards the actualization of accessing the loan, housing delivery and ownership. This is similar to the assertions of Ayedun \& Oluwatobi (2011), Folorunso et al., (2012) and Sivam (2003) who concluded low-income household cannot satisfied the stringent mortgage conditions to access the loans. While Sierminska \& Takhtamanova (2012) opined the mortgage procedures and operations are contrary to the aim of facilitating home ownership.

“Though, our salary is said to have increased to $\$ 30,000.00$, but I don't know how I can get 5 million Naira loan from the salary. My annual salary is about $\$ 408,000.00$, you see, how can I get the said $10 \%$ premium (\$ $500,000.00)$ ? Is not possible." (Participant4).

"I am a labourer with small salary, I told you, for years, I could not save to buy a small piece of land of say 250,000 and now you are asking me saving for 5 million. It is unthinkable" (Participant3)

"Bank loans are very difficult to get, so, with this salary, I'm not thinking along that line. Well, I'm lucky to have bought land and finished the foundation. I'm planning to construct my house gradually" (Participant1)

"You see, they have been deducting from our salaries, but I don't know when I can get the loan from my compulsory saving and I don't know my saving status even." (Participant6)

Considering income levels of the prospective PMIs loan borrowers, it can be concluded, most Nigerians are not energized to access the housing loan, obeying stringent conditions attached. Hence only if one is on a monthly salary of $\$ 100,000$ and intended to take 5 million Naira loan, will take not less than 16 years to save the said $10 \%$ premium ( $\$ 500,000.00$ ) through $2.5 \%$ compulsory monthly deduction otherwise not possible.

On the other hand, it was discovered the interest rate on the loan also scared low and medium income groups to take housing loans. Although, the interest rate of $6 \%$ is considered to be low compared to the commercial banks' interest rate of $15-20 \%$ and the maximum repayable period is 30 years. The repayment amount, should not exceed one third (1/3) of borrower's total monthly net income. However, most of the low and medium income groups considered this as painstaking to fulfil towards owning a house. This is because they perceived it to be high and one cannot finish repayment in his lifetime. This premise, is similar to what Folorunso et al., (2012) supposition, mortgage interest rate on loans, has impeded and scared many prospective loan borrowers from achieving their dream of ever owing a personal house.

"I told you, I'm planning to start my housing construction in piece-meal, you know bank loan, is usually attached with the high-interest rate which will drain you down, even your pension, cannot service the loan and you cannot finish repaying." (Participant1) 
"Taking bank loan is very risky because, you will be repaying throughout your lifetime and at the end of the day, bank will sale your house. I'm not interested in bank loan, the small house I inherited, to be taken away from me after paying for some years. No, I cannot do that." (Participant2).

"I have an experience, my friend collected 'Makama' mortgage loan, then I think was $\$ 6,000.00$ and he had been paying regularly on monthly basis, for 6 consecutive years. Then he was opportune to get a vehicle loan, from his employer and decided to pay off the loan. When he went to FMBN, they gave him a new balance of $\$ 7,350.00$ as if he had not paid anything before. You see, by implication he worked for them for 6 years and at the end, he paid, more than the $\$ 6,000.00$ initially collected. That is how he gets out of the mortgage bondage. So with that experience, I will never go close to it." (Participant4).

"I told you, I am not interested in bank loan, because one cannot repay in short time and all your businesses, will end in servicing the bank loan, and you cannot progress" (Participant7).

In addition, there are other requirements for PMIs housing loan to be satisfied by any intending borrowers, which are equally, difficult as they required incurring some financial expenses and long-time taking (delay). To that ground, the procedures are said to be cumbersome to the prospective borrowers (Ayedun \& Oluwatobi, 2011). However, none of the research participants commented on any of the requirement; these include:

- Approved building plans

- Approve survey/site plans

- Price bill of quantity where applicable

- Valuation report prepared by a firm of registered estate surveyor and valuers where applicable.

\subsection{DISCUSSION}

Although Nigeria governments, made a lot of efforts in trying to solve housing finance problems in the country through establishing apex mortgage institution, PMI and NHF but policies attached to accessing the housing finance are intractably prohibitive to most prospective consumers of the mortgage product. It was found conditions attached, to the mortgage loan, are difficult to satisfy by most prospective mortgage borrowers and or NHF contributors to access the housing funds. It has been the tradition of financial institutions, to have security (collateral) for which loan is applied to guarantee repayment. Under normal circumstances, for a mortgage loan, the collateral usually, is landed property of equal value to the amount of loans. It was discovered, most of the research participants, do not have collateral (landed property) for which, mortgage loan, will be guaranteed as security, therefore, cannot apply for the loan hence they are not qualified. Similarly, it was uncovered few of the research participants with landed property do not have any valid document for which mortgage facility can be accessed like $\mathrm{C}$ of $\mathrm{O}$ or allocation letter, less acquiring for other documents such as a deed of assignment, deed of subleasing and or consent to mortgage. With this scenario, the mortgage loan is impossible to be accessed by low and medium income earners, thereby encumbering housing provision and ownership among many Nigerians.

Economically, households purchasing power are inadequate to save equity premium for accessing housing fund from financial institutions (PMI \& NHF) which obstruct housing provision and ownership in Nigeria. Workers' wages were found to be insufficient to empower low and medium income groups to save for housing development which constitutes unsmiling inhibition to PMI \& NHF housing fund accessibility. Presently minimum wage of employees in Nigeria is increased to $\$ 30,000.00$ hoping to improve households saving capacity. However, this is extremely difficult or rather impossible for the low-income group to contribute $10 \%$ of $\$ 5$ million $(\$ 500,000.00)$ in their 35 years working career. For instance, if the low-income group at $\$ 30,000.00$ minimum wage intended to borrow $\$ 5$ million and $10 \%$ contribution of the equity premium ( $\$ 500,000.00$ ) using $2.5 \%$ compulsory deduction, from monthly salary (\$750.00) will take at least 56 years before qualifying for the housing fund. Only those on $100,000.00$ and $\$ 150,000.00$ salary can save equity premium of 5 million in 17 and 11 years respectively. Table 2 shows the years it took potential contributors to contribute equity for PMI \& NHF loan which ranges from $33-100$ years which is impossible for employees during their 35 years working carrier. This will obviously, hinder accessibility, to the PMI and NHF products, for housing delivery and ownership.

Table 2: Equity contribution based on the new $\$ 30,000.00$ minimum wage

\begin{tabular}{|c|c|c|c|c|c|}
\hline Intended Loan & Save (\%) & Equity & Presumed Salary & Rate 2.5\% & Years to contribute equity \\
\hline$\$ 15,000,000.00$ & 30 & $\$ 4,500,000.00$ & $\$ 150,000$ & $\$ 3,750$ & 100 \\
\hline
\end{tabular}




\begin{tabular}{|c|c|c|c|c|c|}
\hline$\$ 10,000,000.00$ & 20 & $\$ 2,000,000.00$ & $\$ 100,000$ & $\# 2,500$ & 67 \\
\hline N $5,000,000.00$ & 10 & N $500,000.00$ & N 50,000 & $\$ 1,250$ & 33 \\
\hline \# $5,000,000.00$ & 10 & $\# \quad 500,000.00$ & $\# 30,000$ & \# 750 & 56 \\
\hline
\end{tabular}

Source: Author 2020.

Furthermore, it was found stringent conditions and interest rates of the PMIs and NHF housing funds scared prospective loan borrowers and were not interested in mortgage loans that impeded housing development and ownership. Most, of the research participants, expressed their views, that they are not interested in mortgage loans hence, the repayment period is long which is beyond one working carrier and the interest rate is deemed high.

Finance, in general terms, is regarded as a major constraint, to housing provision in many societies especially in less economically developed nations like Nigeria. Housing finance and households incomes are major problems to housing development and ownership of the affordable house by especially, low and medium income earners. Most low and medium income groups do not have sufficient access to formal housing finance, for obvious reasons. Considering conditions attached to the PMIs and NHF housing funds, it is not very much different from that of commercial banks, which required securities, interests and short-term repayment period that make the accessibility difficult. Indeed, the PMIs and NHF housing funds, are surrounded by harsh and restriction conditions like the required equity contribution, collateral and valid documents for obtaining a loan which is extremely difficult for most prospective borrowers (low and medium income earners) to satisfy. Therefore, obtaining the necessary credits to finance housing development is far-reaching by most low and medium income households which necessitated adopting the traditional informal methods of financing and developing houses in piecemeal and warrant using lowquality materials to achieve their dream of owning a house.

\section{CONCLUSION}

Housing provision, is a capital intensive, which requires huge financial obligations, the requirement that is tough to meet by many households, thereby leading to ever-increasing housing stock deficit in Nigeria. Nigeria governments over the years have made efforts toward solving housing finance problems in the country through the establishment of mortgage institutions at different levels to facilitate housing development and ownership among Nigerians. Hence availability and easy process, of obtaining mortgage finance is a key factor to housing development and ownership. However, stringent conditions attached to the mortgage fund's accessibility are cumbersome which make it almost prohibitive for low and medium income groups to access and be empowered to own their houses. Indeed, crack of the matter, lay in the households capabilities to raise funds for financing the construction of their houses since mortgage institutions' fund is not accessible. Therefore, these necessitated the use of the traditional informal methods of housing finance and development. Ironically, the relatively high cost of houses and or housing development, households' income and the financial constraint, over the years has not been corresponding to households' daily demands and saving for housing development which served as a serious clog in the wheel for housing development and ownership. With this scenario, one can conclude by saying, the mortgage financing markets, are yet to effectively develop to solve the housing problems for the low-income group. Therefore, to address these matters of housing fund accessibility, there is need to review the contentious issues of the PMI and NHF policies for housing finance mechanisms to make them practicable and to cover the needs of all income groups. Otherwise, majority of the people will continue to be denied accessibility of the PMI and NHF housing funds and the problems of housing shortage will persist.

\section{SOURCES OF FUNDING}

This research received no specific grant from any funding agency in the public, commercial, or not-for-profit sectors.

\section{CONFLICT OF INTEREST}

The author have declared that no competing interests exist. 
Primary Mortgage Institutions Challenges for Financing Housing Development in Nigeria

\section{ACKNOWLEDGMENT}

None.

\section{REFERENCES}

[1] Abeku, D. M., Salihu, C., \& Kure, M. A. (2016). Housing deficit, urban migration and slum development in Abuja, Nigeria. International Journal of Economic Development Research and Investment, 7(1): 39 - 50.

[2] Ademiluyi, A.I. \& Raji, B.A. (2008). Public and private developers as agents in urban housing delivery in SubSaharan Africa: The situation in Lagos State. Humanity \& Social Sciences Journal, 3(2):143-150.

[3] Ahmed, A. (2014). Primary mortgage institutions as medium for housing finance: a case study of Yankari Savings and Loans Ltd. Bauchi primary mortgage bank.

[4] Akeju, A. A. (2007). Challenges to providing affordable housing in Nigeria. Paper Presented at the 2nd Emerging Urban Africa International Conference on Housing Finance in Nigeria, Held at Shehu Yar'adua Centre Abuja, October 17-19, 2007

[5] Alaka, I. N., Pat-Mbano, E. C., \& Ewulum, N. J. (2012). Contributions of private hostel providers to housing needs of Imo State University Students, at Ugwuorji-Owerri Nigeria. Canadian Social Science, 8(2), 180-186.

[6] Aluko, O. E. (2011). The assessment of housing situation among students in the University of Lagos. African Research Review, an International Multi-Disciplinary Journal, 5(3) serial No. 20, $104-118$.

[7] Ayedun, C.A. and Oluwatobi, A.O. (2011). Issues and challenges militating against the sustainability of affordable housing provision in Nigeria. Business Management Dynamics Vol.1, No.4, pp.01-08.

[8] Berg, B. L. (2001). Qualitative research methods for the social sciences 4th ed. Allyn \& Beacon, Oston.

[9] Bourassa, S., Haurin, D., Hendershott, P., \& Hoesli, M. (2013). Mortgage interest deductions and homeownership: An international survey. Journal of Real Estate Literature, 21(2), 181-203.

[10] Cagamas Holding Berhad (2013). Housing the Nation: Policies, issues and prospects. Institute of strategic and international studies, Malaysia.

[11] Chen, J. \& Deng, L. (2014). Financing affordable housing through compulsory saving: The two-decade experience of housing provident fund in China. Housing Studies, 29(7), 937-958.

[12] Chidi-Okeke, C. N. \& Nwanna, I. O. (2020). The Impact of Primary Mortgage Institutions' Housing Loans on Human Development in Nigeria. IJARD International Journal of Banking and Finance Research. 6(3), 29 - 40.

[13] Creswell, J. W. (2014). A frame work for design. In Creswell, J. W. (Ed.). Research design: qualitative, quantitative \& mixed methods approaches, (2nd ed.). Sage Publication, New Delhi, India.

[14] Federal Government of Nigeria (1992). National Housing Fund Act document.

[15] Federal Mortgage Bank of Nigeria (2016). Federal Mortgage Bank of Nigeria - corporate history. http://www.fmbn.gov.ng/doc/CorporateHistory Retrieved December, 25, 2019.

[16] Federal Mortgage Bank of Nigeria. The role of Federal Mortgage Finance limited in housing finance case study the Federal Mortgage Finance limited Maiduguri. http://www.iproject.com.ng/estate-management/projecttopics/the-role-of-federal-mortgage-finance-limited-in-housing-finance retrieved 261219

[17] Folorunso, C. O., Khan, T. H., \& Olowoyo, S. A. (2012). Trends, realities and prospect of housing delivery through Mortgage Financing in Nigeria. British Journal of Arts and Social Sciences, 7, 134-144.

[18] Ghani, Z.A. (1993). Rural housing development in Dass Local Government Area: Problems and prospects. Unpublish M.Sc. (Urban and Regional Planning) Thesis, Ahmadu Bello University, Zaria.

[19] Gibson, W. \& Brown, A. (2009). Working with qualitative data. SAGE Publications Ltd, London.

[20] Green, R. K., \& LaCour-Little, M. (1999). Some truths about Ostriches: Who doesn't prepay their mortgages and why they don't. Journal of Housing Economics, 8(3), 233-248.

[21] Jiboye, A. D. (2010).The correlates of public housing satisfaction in Lagos, Nigeria. Journal of Geography and Regional Planning, 3(2), 017 - 028.

[22] Keivani, R., \& Werna, E. (2001). Modes of housing provision in developing countries. Progress in planning, 55(2), 65-118.

[23] Lee, C., Ho, Y. \& Chiu, H. (2016). Role of personal conditions, housing properties, private loans, and housing tenure choice. Habitat International, 53, $301-311$. 
[24] MacDonald, H. (2012). Managing the consequences of financial crisis: a long view of housing disposition. Housing Policy Debate 22(2), 201 - 218.

[25] Nubi, T. O. (2000). Housing finance in Nigeria: Need for re-engineering. Department of Estate Management, University of Lagos.

[26] Ojo, A. O., \& Song, H. S. (2009). The Role of Secondary Mortgage Facility in expanding the availability of funds for Mortgage Finance in Nigeria. Unpublished M. Sc. thesis submitted to the department of Real Estate and Construction Management, Royal Institute of Technology (KTH), Sweden.

[27] Omotoso, K. (2011). Mortgage banking/Housing finance sector in Nigeria: past, present and future. Paper presented at Nigerian Real Estate 2011: Market review and market projections. Organized by Mortgage Banking Association of Nigeria (MBAN), Sheraton, on 3rd March 2011.

[28] Population Reference Bureau (2019). 2019 World Population Data Sheet: With a special Focus on youth. Washington DC, USA. https://www.prb.org/wp-content/uploads/2019/03/fp-data-sheet-2019.pdf Retrieved 9/5/2020

[29] Quansah, D. P., \& Debrah, A. A. (2015). Sustainable housing finance in Ghana: The way forward. Real Estate Finance.

[30] Ritchie, J. (2003). The applications of qualitative methods to social research. In Ritchie, J. \& Lewis, J. (Eds.), Qualitative research practice: A guide for social science students and researchers. Sage Publication, New Delhi, India.

[31] Ritchie, J., Lewis, J. \& Elam, G. (2003). Designing and selecting samples. In Ritchie, J. \& Lewis, J. (Eds.) (2003). Qualitative research practice: A guide for social science students and researchers. SAGE publications, India.

[32] Schwartz, A. F. (2006). Housing policy in the United States: An Introduction. Routledge, Taylor \& Francis Group, New York.

[33] Sierminska, E. \& Takhtamanova, Y. (2012). Financial and housing wealth and consumption spending: Crosscountry and age group comparisons. Housing Studies, 27(5), 685-719.

[34] Sivam, A. (2003). Housing supply in Delhi. Cities, 20(2), 135-141. 